\title{
Introduction to the Janet Norwood memorial papers
}

\author{
Kirsten West \\ Interview Editor SJIOAS \\ Tel.: +1 443745 4665; E-mail: kwestiaos@gmail.com
}

The formal adoption of the UN Fundamental Principles of Official Statistics has been recognized in several issues of our Journal this year. It began in March with a paper by Steve Pierson, comparing the Fundamental Principles with selected similar codes elsewhere. In the June issue we continued with illustrations of the practice of official statistics, guided by these principles, in two different countries, Greece and Norway. In this issue of the Journal, you will find comments from Germany and Suriname. But wait there is a lot more than principles here; the real living examples of these principles are in the persons who have exemplified them. Hence, in this section, we honor the legacy of Janet Norwood.

\section{Background on Dr. Janet Norwood}

On March 27, 2015 the international statistical community lost one of its finest members. Janet Norwood passed away at the age of 91 from complications of Alzheimer's disease. She was a stalwart proponent of the principles for production, presentation and dissemination of official statistics and a role model for official statisticians, then and now. Her political impartiality was legendary. Her determination to maintain the independence of Official Statistics was unsurpassed!

Janet Norwood was the Commissioner of the U.S. Bureau of Labor Statistics (BLS) for thirteen years and the first female to hold that position. She set high standards as a public servant. She never strayed from objectivity in interpreting data. She was resolute and staunch in adhering to the principles of official statistics.

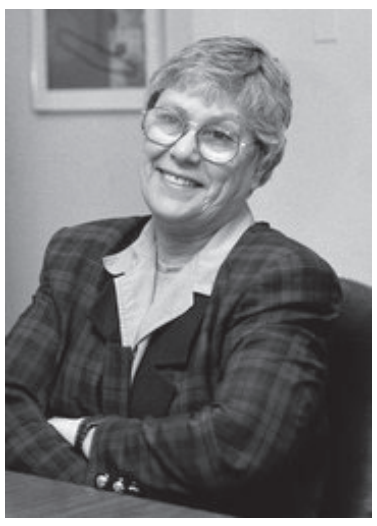

Dr. Norwood was dedicated to her work and to public service and she made her mark on the profession in many, many ways. During her tenure at BLS, she oversaw technical improvements to the Consumer Price Program, for example, by implementing revisions to the homeownership component of the Consumer Price Index (CPI). But, as you will read below, it was her command for the detail worth telling that will never be forgotten.

In recognition of her excellence in management, Dr. Norwood was awarded Presidential Rank as Distinguished Executive in the U.S. Senior Executive Service (SES). She was elected President of the American Statistical Association (ASA) in 1989 and later on vice president of the International Statistical Institute (ISI).

She served as head, board member, or senior adviser in official statistical posts too numerous to mention. Many other governments sought her advice on gathering and analyzing statistics, the Canadian Government and the EU among them. 
As her husband of 71 years, Bernard Norwood, said in his eulogy to her "she was [always] confident in her command of the issues and clear in her explanations." She was still in college when the couple met. The early years of their marriage were dominated by World War II. Bernie went to war and saw front line combat. As he self-deprecatingly put it, he went on "a hunting and camping expedition with General Eisenhower in Europe.” He received a Purple Heart. Janet started graduate school while he was away. After the war, Bernard also completed graduate studies and in 1949, the Norwoods arrived in Washington. Bernie had a new job with the State Department. Janet began what would become a lifelong career with labor statistics. She also wrote and published extensively on international trade policy matters.

Soon, her husband's first Foreign Service assignment as a member of the U.S. Mission to the European Communities took them to Luxembourg and Belgium. During their five-year stay in Europe, the couple got involved in the early stages of the formation of what is now the European Union. Janet organized study groups on the United States for the wives of officials of the European Communities and integrated her family in the activities of the international community.

Upon their return to the States, Janet took a job as part-time junior economist with the Department of Labor. Her husband noted that "she thrived and moved up rather impressively" within the department. Along the way, she added on additional academic training, taking courses at the U.S. Department of Agriculture's graduate school and at The George Washington University.

In those days, it was rare for women to move into top management positions in US federal agencies. But in 1975, Janet Norwood became BLS Deputy Commissioner and in 1979, she was appointed to serve as BLS Commissioner.

As Commissioner, she appeared for many years before the Congressional Joint Economic Committee on the first Friday of every month the Congress was in session. The purpose of those public hearings was the release of the employment data. In her testimonies, she never made statements that could be exploited as a weakness or as failures of the party in power.

Her tenure as Commissioner included appointments, initially by Democratic President Jimmy Carter and twice by Republican President Ronald Reagan. "She did not serve political ends, but did what she perceived to be right for the people."
Janet Norwood will be remembered for her integrity, professionalism, and impartiality. We reprint here with permission four speeches from her memorial celebration. The celebration occurred at the Cosmos Club in Washington, D.C. this spring.

Ever the trail-blazer, Dr. Norwood was among the first group of women to be admitted to the Cosmos Club and she was later to be its first female president.

We include two memorial speeches that illustrate her place in the federal statistical system by Connie Citro and Tom Plewes. In his eulogy, Tom Plewes emphasizes Janet's steadfast advancement of the quality, integrity, reliability and objectivity of federal statistics. Tom Plewes is Director of the Committee on Population of the National Academy of Sciences and a Senior Program Officer for the Committee on National Statistics (CNSTAT). He served as the Associate Commissioner for Employment and Unemployment Statistics of the Bureau of Labor Statistics under Commissioner Norwood.

Connie Citro talks about Janet's leadership roles, and her impressive technical skills, noting that Norwood was the "dean of the federal statistical system." Dr. Citro is currently Director of the Committee on National Statistics (CNSTAT), a position she has held since 2004.

The speeches given by her sons, Stephen and Peter, both distinguished professionals in their own right, make it clear that Janet Norwood also had many other personal achievements not yet mentioned. She earned her doctorate at the Fletcher School of Law and Diplomacy at Tufts University in Boston, Massachusetts at a time when many women were not holding graduate degrees.

Stephen Norwood, Professor of History, University of Oklahoma, recalls that none of his friends or acquaintances had mothers with a doctorate degree. She also excelled as an athlete. "She taught me how to use a baseball glove." Peter Norwood shares the lessons he learned from his mother about family, parenthood, marriage, feminism, work ethics, and how to be a good manager. "She left me with a model for how to live a good life." Peter Norwood is Director of Engineering at Google.

All who knew her will miss her and those Official Statisticians who did not have that chance may still profit by reading the remembrances that follow. 